\title{
Comparative-Causal Study of the Immigration's Term in Students of the University of Granada, Spain
}

\author{
Clemente Rodriguez-Sabiote ${ }^{1}$ \\ Universidad de Granada, Granada, \\ España
}

\author{
Jose Alvarez-Rodríguez \\ Universidad de Granada, Granada, \\ España
}

\author{
Rosa Pilar Gamez-Durán \\ Junta de Andalucía, Granada, \\ España
}

\begin{abstract}
This study, of comparative-causal type, cutting wants to determine if different variables inherent to the students of the University of Granada (as the genre, degree where they study, etc.) influence in the way they assess the term of "inmigration". We use a survey that evaluated the perception of agree vs disagree on the term "inmigrantion" of a sample $(N=423)$ students of this university selected by cluster random sampling. The obtained results show that, really, some of the referred variables have shown to be relevant when assessing with varying agreement to the concept previously mentioned, over all, regarding the different degrees, ideology and the students economic situation, the object of the research.
\end{abstract}

Keywords: attitudes, immigration, higher education

\section{Estudo Comparativo-Causal do Termo Imigração em Estudantes da Universidade de Granada, Espanha}

\begin{abstract}
Resumo: O presente estudo, de corte comparativo-causal, pretende verificar se diferentes variáveis inerentes aos estudantes da Universidade de Granada (como o gênero, a titulação onde cursam seus estudos, dentre outras) afetam a forma como avaliam o termo "imigração". Foi utilizado um inventário que avaliou a percepção sobre o agrado versus desagrado do termo referido de uma amostra de $(N=423)$ alunos desta universidade selecionada através de uma amostragem probabilística por conglomerados. Os resultados obtidos destacam que, de fato, algumas das variáveis referidas foram relevantes na hora de avaliar positiva ou negativamente o termo imigração, sobretudo, no que diz respeito às variáveis titulação, ideologia e situação econômica dos estudantes da nossa pesquisa.
\end{abstract}

Palavras-chave: atitudes, imigração, ensino superior

\section{Estudio Comparativo-Causal del Término Inmigración en Estudiantes de la Universidad de Granada, España}

\begin{abstract}
Resumen: El presente estudio, de corte comparativo-causal, pretende determinar si diferentes variables consustanciales al alumnado de la Universidad de Granada (como el género, titulación donde desarrolla sus estudios, etc.) inciden en la forma en cómo valoran el término de "inmigración". Para ello utilizamos un inventario que ha evaluado la percepción de agrado vs desagrado de dicho término de una muestra de estudiantes $(N=423)$ de la dicha universidad seleccionados mediante un muestreo probabilístico por conglomerados. Los resultados obtenidos apuntan a que, efectivamente, algunas de las variables contempladas han resultado relevantes a la hora de valorar con mayor o menor agrado el concepto anteriormente mencionado, sobre todo, por lo que respecta a las variables titulación, ideología y situación económica del alumnado objeto de la investigación.
\end{abstract}

Palabras clave: actitudes, inmigración, educación superior

From 1998 to 2008, Spain was a destination country of numerous flows of immigration of varied origin until the arrival of the economic crisis in 2008. Many of those immigrants and others who arrived in Spain even earlier are parents of children who were born in Spain and whose cultural and national identity has certainly been blurred between the country of origin of their parents and the host country. In this sense, it is possible that although they are Spaniards, they are not fully accepted by the host community, and when they travel to their parents' country, they are also

\footnotetext{
${ }^{1}$ Correspondence address:

Clemente Rodríguez-Sabiote. Departamento de Métodos de Investigación y Diagnóstico en Educación, Facultad de Ciencias de la Educación, Campus de Cartuja, s/n 18071. Granada, España. E-mail: clerosa@ugr.es
}

considered foreigners. On the other hand, Europe is currently experiencing a crisis of refugees from Syria and other areas and countries in conflict. Horrific (e.g., the baby drowned and stranded on a Turkish beach) and shameful (e.g., the tripping by a Hungarian journalist of a Syrian refugee to obtain the snapshot that catapulted her to the Pulitzer of ignominy) images have been captured. In this situation, Europe is allowing the arrival of contingents of refugees to spread over several countries, which will certainly not be to the liking of certain sectors of the citizenship of some of these host countries, particularly after the repudiable incidents committed against Western women by men of supposed Muslim ethnicity in German cities on New Year's Eve in 2015. Additionally, although Spain is not Germany, France, the Netherlands, or 
Denmark, where xenophobic radical right-wing parties are gaining support, it is necessary, almost mandatory, to know the opinion of its citizens on the phenomenon of immigration. In this respect, a recent paper by Rinken (2015) shows that the rejection of immigration in Spain is not as intense as it is in other European countries. The cited author highlights four fundamental hypotheses that could explain why Spaniards are exceptional in this regard. First, it has been argued that the political culture of post-Franco Spain assumes the overcoming of backward suspicions, fostering open attitudes towards immigration and immigrants (Arango, 2013). Second, there is so-called social desirability (Phillips \& Clancy, 1972) or the pretence of expressing desirable and politically correct notions when one thinks otherwise. In this context, it is Rinken (2015) who stresses that sooner or later, the tension between real and declared opinions could be excessive. Third, Spanish exceptionalism would not be indefinite. Fourth, the very perception of the crisis and its effects would be motivating relatively relaxed attitudes towards immigrants; thus, the paradox would be only apparent and would become the core of the explanation of citizen calm on matters of immigration.

Another still more recent study, that of Martínez de Lizarrondo (2016), concludes in relation to the possible taking of jobs from natives (Spaniards) by immigrants that in the regions of Spain where the difference in the unemployment rate between immigrants and natives is higher, there are more naturalizations. Conversely, where there is no particular advantage in improving unemployment if Spanish nationality is acquired, because the rate is very similar between immigrants and Spaniards, then there are fewer naturalizations. All this notwithstanding, we think that it is critical to know the opinion of a group with a vision of the future such as our university students, particularly those who are about to finish their university studies, that is, those who are finishing the last year of their degree. For this reason, as agents on the verge of undertaking vital social and economic cycles, they can be considered a relevant sample of the citizenry's feelings about the pleasure and displeasure generated by the word immigration in a part of the society of Granada.

In addition, we cannot deny that there has been a great deal of concern in the European Union for some time due to the rise of xenophobic and racist attitudes towards minority groups and immigrants (citizens from emerging or developing countries), as shown in the study conducted by the European Monitoring Centre on Racism and Xenophobia (Thalhammer, Zucha, Enzenhofer, Salfinger, \& Ogris, 2001). In the same line, in later studies, such as those by León del Barco, Mira, and Gómez Carroza (2007), who study a sample of university students, Balch (2010), Martín-Artiles, and Meardi (2013), Martín-Artiles and Molina (2011), Naranjo Giraldo (2015), and Narvaiza, Laka, and Silvestre (2007), who reveal a set of key variables to be studied to understand the attitudes of the European population towards the immigration process, the main conclusions reached point to the manifest rejection by the citizenry of some European Union countries of these minority and immigrant groups, articulated in three different aspects. First, the unemployment rate seems to be associated with attitudes of rejection towards these groups. The second aspect is that countries with greater spending on social protection and lower social inequalities seem to contribute to more favourable attitudes towards immigration. The third aspect is that ethnic and racial heterogeneity does not seem to favour commitment to equality, showing that this variety of ethnic groups favours an attitude of rejection, suspicion, and lack of solidarity in the European population with the creation of ghetto neighbourhoods that have little or no interaction with the native citizenry.

The Spanish population has not been unaware of this process. Until the onset of the crisis between the end of 2007 and the beginning of 2008, there was a long period of economic prosperity. In this context, from the late 1990s to 2007, Spain received large numbers of immigrants of different nationalities, generating a large demand for jobs. In this sense, we must note that from the Permanent Migration Observatory of Andalusia (OPAM) (2013), it is clear that "from 1998 to 2007, more than 6 million jobs were created in Spain, $40 \%$ of which were filled by foreigners" (OPAM, 2013, p. 2). From this point on, there has been greater attention to economic and social policies to meet the demand for both employment and integration of all these foreign populations in the Andalusian and, therefore, Spanish territory (OPAM, 2011, 2012).

It is important to emphasize how simultaneously as the economic crisis developed, opinions on immigration in Spain have been growing worse. This idea is argued in current studies, such as those by Rinken $(2012,2013 a, 2013 b)$ and Rinken and Escobar Villegas (2012).

Against this backdrop and considering other studies, such as those by Domínguez-Mujica, Guerra- Talavera, and Parreño-Castellano (2014), Gualda and Ruiz Garcia (2005), Holgado Tello, Sánchez Bravo, and Navas Martínez (2011), Molino Alonso (2007), Portes (2009), Rinken and Escobar Villegas (2012), and Villén, Sola, and Hinojo (2013), there is a growing concern among the citizenry regarding immigration in times of economic recession. As López-Sala and Oso (2015) affirm, the most innovative Spanish scientific research on immigration has brought to light the differential impact between native Spaniards and immigrants, according to the different phases of the economic recession that has occurred in Spain. Against this backdrop, we firmly believe that it is important to unravel the attitude towards the concept of immigration held by a sample of students of the University of Granada for two fundamental reasons. The first is that in these studies, it is concluded that the economic crisis in which Spain is involved is generating a less progressive opinion on the concept of immigration, although many immigrants have left the Spanish territory, given the poor economic situation. The second is that some of these studies also reveal that at the level of university students, there are also prejudices and rejection of the immigrant group. For this reason, we have conducted the present investigation. Its main purpose is to discover whether a series of variables that characterize the students of the University of Granada under study has an influence, or not, when forming a better or worse opinion of the concept of immigration and to be able to consequently elaborate a profile of students who are in solidarity with immigrants and another of students who reject them. This strategy is followed 
because we believe that some variables, such as the type of degree and the ideology of the students (we assume, by way of hypothesis, that Social Education students and students who are considered centre-left will be more supportive) and, for example, whether the students have migrant relatives, as in the case of Villén et al. (2013), may generate greater or lesser agreement with the term immigration.

Therefore, the objectives of the present study are (a) to know the degree of favourable vs. unfavourable reaction generated by the term immigration among the students under study in their final year at the University of Granada; (B) to determine the degree of favourable vs. unfavourable reaction to the word immigration according to a set of determining variables that characterize the sample under study: faculty of origin, specialization, gender, ideology with which they most identify, family economic situation, and claimed degree of religiosity; and (c) to verify whether there are significant differences in the degree of sympathy or rejection stimulated by the term immigration according to the set of variables previously explained and to elaborate a pro- or anti-immigration student profile from the variables that characterize the students under study.

\section{Method}

Along with Babbie (2000), Bisquerra Alzina (2004) and Cohen, Manion, and Morrison (2010), this research can be included in the so-called ex post facto methodology, more precisely, as a comparative-causal study (Niño Rojas, 2011). The reason is that, as shown below, the different opinions of the students have been valued and compared with some nonmanipulable attributive variables, such as gender and major, among others.

\section{Participants}

The population under study consists of all students in their final year of study at the University of Granada. The sample is composed of 423 students (411 after the loss of 12 cases), eight majors, and two different fields of knowledge specified in subsequent sections. For the calculation of the sample size, the following parameters were considered: the starting population $P=5000$ students in their final year; confidence level $1-\alpha=.95$; sample error $=4.55 \%$; and probabilities $p=q=.5$.

For the selection of this sample, we used the probabilistic sampling method by clusters (Clairin and Brion, 2001, De la Garza Toledo and Leyva, 2012; Meltzoff, 2000), consisting of three different units: the primary unit, field of knowledge; the secondary unit, faculty; and the final unit, major. In the three stages, the so-called simple random sampling through a lottery system was used as a secondary strategy for the selection of the units. Thus, for the primary unit, two out of four possible fields of knowledge were randomly selected: Experimental Sciences and Social and Legal Sciences. For the secondary unit, three faculties of the fields of knowledge noted were also selected: Sciences, Education Sciences and Economics and Business Sciences. Finally, for the tertiary unit, eight majors were selected: Biology, Mathematics, Biochemistry, and Economics, as well as Business, Foreign Language, Music, and Social Education diplomas. Once the majors were selected, the in situ administration of the data collection instrument was performed in the classrooms of the last year for the majors ultimately selected. In relation to the participation of the students under study, note that they participated freely in the study and with full knowledge of the purpose.

\section{Instrument}

For the collection of information, we used a scale consisting of 250 words in which the students had to rate each word on a scale ranging from 1 to 5 , according to their level of displeasure or pleasure, with 1 being very unpleasant and 5 very pleasant. The instrument in question is called the Axiological Test and was re-elaborated from the Garcia Hoz's (1976) Valuation Reaction Test by the Emerging Values and Social Education research group (HUM.580) of the University of Granada (Spain). This test consists of 10 axiological typologies, namely, corporeal, intellectual, affective, individual, aesthetic, moral, social, ecological, instrumental, and religious. In our case, we have only contemplated the valuation of the word immigration, number 156 on the scale of 250 words, which belongs to the category of social values. In relation to the quality parameters of the scale as a whole (the 250 words), we considered reliability as internal consistency, having obtained a Cronbach's $\alpha$ coefficient value of .96. As validity of the scale, we considered the validity of content guaranteed through the use of a previously standardized scale, in addition to criterial validity. For the latter, we calculated the corrected item-total correlation coefficient, with a majority of corrected item-total coefficients above $r=.20$. These results indicate that items (words) individually measure the same as the scale as a whole.

\section{Procedure}

Data collection. The administration of the instrument was performed by several surveyors who had previously been trained to correctly apply it. The sample was informed of the purposes of the investigation and of its voluntary, anonymous, and unpaid nature.

Data analysis. In line with the proposed research objectives, we conducted a collection of descriptive and inferential analyses using the SPSS v.22 program and organized around the fulfilment of the three proposed research objectives.

\section{Results}

\section{General}

First, we attempt to discover the degree of favourable reaction to the term immigration in the sample under study. The most striking descriptive results are the following. First, at the global level, the word immigration receives a moderately good reception, given that $54.1 \%$ of the students surveyed, more than half, respond pleasant or very pleasant. 
For $32.1 \%$, which is in fact a considerable percentage, the response is indifferent, and only the remaining $13.8 \%$ report it as unpleasant or very unpleasant. In relation to the overall arithmetic mean obtained, a value of 3.56 out of a maximum of 5 shows a moderate favourable reaction, in agreement with the obtained percentage measures. The resulting standard deviation of 1.03 indicates a certain homogeneity in the assigned scores, with clear evidence of a concentration of values around the middle of the data distribution.

\section{Comparison on each of the identification variables considered}

Second, we attempt to determine the degree of sympathy towards the word immigration, taking different variables and the levels that constitute them as a comparative element:

According to the variable of faculty under study. In relation to the variable of faculty, we can observe how, globally, the three faculties under study obtain averages above 3, which place them between indifferent and pleasant. The faculties of Economics and Business (average of 3.48), Sciences (average of 3.60), and Education Sciences (average of 3.69) are positioned from the lowest to the highest degree of acceptance. The highest dispersion of assigned scores is obtained in the faculty of Economics and Business (standard deviation of 1.06), whereas the lowest is obtained in Education Sciences (standard deviation of 0.95).

According to the variable of specialization of studies. Taking as reference the variable of specialty, we can observe how, globally, all specialties under study reach arithmetic means above 3 , the central point of the values beyond which the values begin to tend towards the pleasant of the five categories of possible responses. However, the Bachelor of Biochemistry and Social Education should be noted as totally opposed points. In this respect, the former specialty (Bachelor of Biochemistry, with an average of 3.23) is shown to be the specialty in which the word immigration obtains the lowest valuation. Confronting it is positioned the Social Education degree (average of 4.32), the specialty in which the highest valuation for the same word is obtained. In descending order, these are the results of the other specialties: Bachelor of Mathematics (average of 3.71) > Bachelor of Biology (average of 3.68) $>$ Bachelor of Economics (average of 3.54) $>$ Foreign Language Diploma, English (3.49) > Diploma in Music Education (average of 3.35).

In relation to the variability of the opinions expressed, we can appreciate the Social Education diploma (standard deviation of .81), in which the greatest consensus is achieved; in contrast, for the Mathematics degree (standard deviation of $1.15)$, there is the least consensus.

According to the variable of gender. In terms of the results obtained, we can observe that women (mean of 3.62) value the word immigration slightly better than men (mean, 3.43). In both cases, the averages are above the central point, with a tendency towards the pleasant for the possible total of points. Regarding variability, there is a greater consensus among women (standard deviation .99) than among men (standard deviation 1.1).

\section{According to the variable of political ideology with} which they are identified. Taking as reference the results obtained when crossing the variable of political ideology with the degree of sympathy stimulated by the word immigration, we can affirm that the university students who identified with a left, centre-left, and centre ideology (averages of 4, 3.69, and 3.6, respectively) show a higher degree of sympathy for the word immigration than those of the centre-right and the right (averages of 3.30 and 2.7 respectively). In the middle (average of 3.43) are positioned the university students who are shown to be ideologically indifferent.

On the other hand, it is the students who identify with the centre-right ideology who show the greatest consensus when assessing the criterion variable under study (standard deviation of .88), whereas those of the right have the highest heterogeneity of opinions (standard deviation of 1.26).

According to the degree of religious practice and/or religious positioning. As with the political ideology variable, the university students who say that they do not practice any religion, as well as being in an agnostic and atheistic position, value the word immigration more positively (averages of 4 , $3.85,3.8$, and 3.57). On the other hand, the students who claim to be practitioners of a religion (average 3.44) are those who value this word with less sympathy. However, no average falls below 3; thus, we cannot say that any religious position globally values the word badly. In relation to consensus, those who are indifferent show the lowest variability (standard deviation of .91), whereas atheists are those with the greatest dispersion (standard deviation of 1.09).

According to the family economic situation. Finally, taking as reference the variable of economic situation, we can observe that for a better economic situation (good, with an average of 3.2, and regular, with an average of 3.63), the degree of favourable reaction to the word immigration is lower. On the other hand, for worse economic situations (bad, with an average of 3.52, and very bad, with an average of 4), this valuation is greater. Regardless, as with the other reference variables, it is not possible to globally affirm that there is antipathy towards the term under study because all averages are above the limit value of 3 (out of a maximum of 5).

In relation to the degree of variability of the opinions expressed, the students with a good economic situation are those with the highest dispersion in opinion (standard deviation of 1.13), whereas those with a poor economic status reach the most consensus (standard deviation of .9).

\section{Significance tests}

Third, to attempt to denote whether there are significant differences between the different levels that constitute the relevant variables contemplated in relation to the degree of sympathy towards the word immigration, we conduct some analyses of a clearly inferential nature. Because all of the variables involved, except gender, have more than two levels and come from independent samples, as well as the fact that there is a violation of some of the parametric assumptions, specifically normality, we decide to use non-parametric tests for two and " $\mathrm{K}$ " independent 
samples, more specifically, Mann-Whitney U tests (two samples) and one-way ANOVA of $\mathrm{H}$ of the Kruskal-Wallis test (K samples). In addition, paired post hoc contrasts are implemented. A summary of the results obtained in these tests is shown in Table 1.

Table 1

Summary of the results of the non-parametric contrast tests implemented when crossing each independent variable with the assessment of the word immigrant

\begin{tabular}{llc}
\hline \multicolumn{1}{c}{ Variable } & \multicolumn{1}{c}{ Test } & Significance \\
\hline Gender & Mann-Whitney & .140 \\
Specialty & Kruskal-Wallis & $.001^{* * *}$ \\
Ideology & Kruskal-Wallis & $.000^{* * *}$ \\
Religiosity & Kruskal-Wallis & .163 \\
Economic situation & Kruskal-Wallis & $.031^{*}$ \\
Faculty & Kruskal-Wallis & .356 \\
\hline
\end{tabular}

Note. ${ }^{*} p<.05 . * * p<.01 .{ }^{* * *} p<.001$.

As we can observe, three variables (independent) of the six contemplated have marked significant differences, $p$ $<.05$, when crossed with the criterion variable assessment of the word immigration. These variables are specialty, political ideology, and family economic situation. This result implies that the degree of favourable vs. unfavourable reaction to the word immigration is very different depending on whether the students in question study one or another specialty, are positioned in one or another political ideology, or belong to more or less economically well-off families. In this sense, in relation to the variable of specialty, we can affirm that it is, above all, the Diploma of Social Education that most positively values the word immigration far above the rest. Recall that the average for this specialty is 4.32 whereas the other specialties are placed with averages slightly or moderately above 3 .

In fact, the post hoc contrasts subsequently implemented reveal that this specialty is the only one with significant differences, $p<.001$, specifically, with the specialties of Biochemistry, Music Education, Foreign Language, and Business. In relation to the political ideology variable, we can observe that the students who identify with an ideology of the left, centre, and centre-left, in addition to those who declare themselves to be ideologically indifferent, value the word immigration more positively, with averages between 3.43 and 4. However, those who identify with a right and a centre-right political ideology are less favourable to the term under study. The right-wing students warrant special mention (mean 2.70); compared to the post hoc contrasts with the rest of the ideological positions, they have significant differences associated with probabilities of $p<.001$ and $p<.05$, depending on the pair compared.

With respect to the variable of economic level, we can say that students from families with less monetary resources (very bad economic situations, average of 4 , and poor, average of 3.52) show a higher level of favourable reaction to the word immigration, whereas those corresponding to more affluent families (regular economic situations, average of 3.63, and good, average of 3.20) show less favour towards this term. In addition, the post hoc contrasts implemented show significant differences only between good and very bad family situations and between bad and very bad situations, in both cases with probabilities of $p<.05$.

\section{Discussion}

The sample of students at the University of Granada under study shows a weakly favourable reaction to the word immigration (global mean of 3.56 between indifference and pleasant) based on a maximum value of 5 . It is therefore of concern that almost half of the respondents (189) place their opinion in the grades of very unpleasant (15 students), unpleasant (42 students), and indifferent (132 students), not so much by the negativity of their opinions as by their degree of indifference towards the term evaluated.

Of the six variables of identification considered, three have marked significant differences: specialty, political ideology, and familial economic situation. The remaining variables, i.e., gender, faculty, and religiosity, however, do not report significant differences. From this second aspect, we derive a set of findings of a more specific nature that we explain in the following section of conclusions of the study.

To conclude, we have inferred a series of conclusions that we show below, still assuming that there is empirical evidence on the volatility of this type of attitudinal scale throughout the training processes for university students, depending on the degree and the years that they are in their career. The first is that of all the results presented by specialty, the students of the University of Granada who specialize in Social Education have the highest degree of sympathy regarding the term immigration. In fact, they are far removed from the opinion of the Biochemistry, Business, and Foreign Language students (those of less sympathy), though slightly less distant from the other specialties involved in the study.

The second conclusion is that the students who claim to identify with a right-wing and a centre-right ideology claim to have a less favourable reaction to the term immigration than those who claim to identify with a centre-left ideology.

Third, the students with a very poor family economic level (the less affluent who have lower incomes) show a more favourable reaction to the term immigration than that shown by those of a poor or regular economic family background and, above all, a good economic family background. Finally, although not significant, the gender, faculty, and religiosity variables have also reported different averages on the degree of sympathy for the concept of immigration. In light of all these conclusions, we can establish profiles of university graduates of the University of Granada who are more or less favourable to the term immigration. In this manner, we can conclude that the profile of students of the University of Granada under study who are more favourable to the term immigration are women who study Education Sciences, specifically, those who specialize in Social Education who identify with centre and centre-left political ideologies, claim to feel atheistic and, religiously, practise little or nothing, and come from families with a very poor economic situation. In contrast, we can affirm that the profile of students who are 
less favourable to the term immigration are men who study Economics and Business and Natural Sciences, fundamentally those who specialize in Biochemistry who identify with political ideologies of the right and the centre-right, claim to be believers and practitioners on a religious level, and belong to families with a better economic situation.

\section{References}

Arango, J. (2013). Exceptional in Europe? Spain's experience with immigration and integration. Washington, DC: Migration Policy Institute. Retrieved from http://www. migrationpolicy.org/research/exceptional-europe-spainsexperience-immigration-and-integration

Babbie, E. (2000). Fundamentos de la investigación social (J. F. J. Dávila Martínez, Trad.). México, DF: International Thomson.

Balch, A. (2010). Economic migration and the politics of hospitality in Spain: Ideas and policy change. Politics \& Policy, 38(5), 1037-1064. doi:10.1111/j.17471346.2010.00263.x

Bisquerra Alzina, R. (2004). Metodología de la investigación educativa [Research methodology of education]. Madrid, Spain: La Muralla.

Clairin, R., \& Brion, P. (2001). Manual de muestreo [Handbook of sampling]. Madrid, Spain: La Muralla.

Cohen, L., Manion, L., \& Morrison, K. (2010). Research methods in education (7th ed). New York, NY: Routlegde.

De la Garza Toledo, E., \& Leyva, G. (Eds.). (2012). Tratado de metodología de las ciencias sociales: Perspectivas actuales [Handbook of methodology of social sciences: Current perspectives]. México, DF: FCE/UAM.

Domínguez-Mujica, J., Guerra-Talavera, R., \& ParreñoCastellano, J. M. (2014). Migration at a time of global economic: The situation in Spain. International Migration, 52(6), 113-127. doi:10.1111/imig.12023

García Hoz, V. (1976). Test de reacción valorativa [Reaction value test]. Bordón: Revista de Pedagogía, (214), 245-270.

Gualda, E., \& Ruiz García, M. (2005). Procesos de sustitución étnica e inserción sociolaboral de mujeres extranjeras en Huelva [Substitution processes of ethnic and social and professional integration of foreign women in Huelva]. Trabajo: Revista Iberoamericana de Relaciones Laborales, (15), 177-193.

Holgado Tello, F. P., Sánchez Bravo, A., \& Navas Martínez, L. (2011). Análisis de la estructura de la escala de actitudes hacia la Inmigración en una muestra estudiantes chilenos [Structure of Attitudes toward Immigration Scale in a chilean sample]. Revista Iberoamericana de Diagnóstico e Avaliação Psicológica, 1(29), 97-113. http://www.aidep. org/03_ridep/R29/r29art5.pdf
León del Barco, B., Mira, A. R., \& Gómez Carroza, T. (2007). Evaluación de las opiniones sobre la inmigración y la multiculturalidad en la escuela de alumnos de Magisterio [An evaluation of opinions concerning immigration and multiculturality in the School for Teacher Training]. Revista de Investigación Psicoeducativa, 5(2), 121-138. Retrieved from http://www.investigacion-psicopedagogica.org/revista/ articulos/12/espannol/Art 12_175. pdf

López-Sala, A., \& Oso, L. (2015). Inmigración en tiempos de crisis: Dinámicas de movilidad emergentes y nuevos impactos sociales [Inmigration in times of crisis: Dynamics of emerging mobility and new social impacts]. Migraciones: Revista del Instituto Universitario sobre Migraciones, (37), 9-27. doi:10.14422/mig.i37.y2015.001

Martín-Artiles, A., \& Meardi, G. (2013). Actitudes hacia la inmigración y compromiso igualitario en Europa [Attitude towards immigration and egalitarian compromisse in Europe]. Política y Sociedad, 50(2), 629-656. doi:10.5209/ rev_POSO.2013.v50.n2.38221.

Martín-Artiles, A., \& Molina, O. (2011). Crisis, economic uncertainty and unions members attitudes towards immigration in Europe. Transfer: European Review of Labour and Research, 17(4), 453-470. doi:10.1177/1024258911419752.

Martínez de Lizarrondo, A. (2016). Naturalizaciones en España: Indicador de integración y estrategia frente a la crisis [Naturalizations in Spain: Integration indicator and the strategy against the crisis]. Migraciones: Revista del Instituto Universitario sobre Migraciones, (39), 3-37. doi:10.14422/mig.i39y2016.001

Meltzoff, J. (2000). Crítica a la investigación: Psicología $y$ campos afines [Critical thinking about research: Psychology and related fields]. Madrid, Spain: Alianza Editorial.

Molero Alonso, F. (2007). El estudio del prejuicio en la psicología social: Definición y causas [Study of prejudice in social phychology]. In J. F. Morales, E. Gaviria, M. C. Moya Morales, \& M. I. Cuadrado Guirado (Coords.), Psicología social (pp. 591-617). Madrid, Spain: McGraw-Hill.

Naranjo Giraldo, G. E. (2015). El nexo migracióndesplazamiento-asilo en el orden fronterizo de las cosas. Una propuesta analítica [The Nexus migrationdisplacement-refuge in the order of things at the border. An analytical approach]. Estudios Políticos, (47), 265284. doi:10.17533/udea.espo.n47a15

Narvaiza, J. L., Laka, J. P., \& Silvestre, M. (2007). Actitudes frente a la inmigración extranjera [Attitude towards foreign immigration]. Lejona, Spain: Ikuspegi Observatorio Vasco de Inmigración.

Niño-Rojas, V. M. (2011). Metodología de la investigación: Diseño y ejecución [Methodology of researcyh: Design and implementation]. Bogotá, Colombia: Ediciones de la Universidad. 
Observatorio Permanente Andaluz de las Migraciones. (2011). Informe anual Andalucía e Inmigración 2010. Sevilla, España: Dirección General de Coordinación de Políticas Migratorias/Conserjería de Empleo/Junta de Andalucía. Retrieved from http://www.juntadeandalucia. es/justiciaeinterior/opam/sites/default/files/DOC/ informe 2010/informe 2010.html

Observatorio Permanente Andaluz de las Migraciones. (2012). Evolución y características principales de los inmigracions nacionalizados en España. Tema OPAM, (6), 1-12. Retrieved from http://www.juntadeandalucia. es/justiciaeinterior/opam/sites/default/files/DOC/Tema_ OPAM_6_Junio_2012.pdf

Observatorio Permanente Andaluz de las Migraciones. (2013). España, ¿país de emigración? La imagen de éxodo, a prueba de evidencia estadística. Tema OPAM, (8), 1-12. Retrieved from http://digital.csic.es/bitstream/10261/79094/1/ TemaOPAM_n8_Junio2013-WEB.pdf

Phillips, D. L., \& Clancy, K. J. (1972). Some effects of "Social Desirability" in survey studies. American Journal of Sociology, 77(5), 921-940. doi:10.1086/225231

Portes, A. (2009). Migración y cambio social: Algunas reflexiones conceptuales [Migration and social change: Some conceptual reflections]. Revista Española de Sociología, (12), 9-37.

Rinken, S. (2012). El impacto de la crisis sobre la opinión pública ante la inmigración [Crisis impact in public opinion towards immigration]. In E. Gualda Caballero (Ed.), Inmigración, ciudadanía y gestión de la diversidad (pp. 221-242). Sevilla, Spain: Universidad Internacional de Andalucía.

Rinken, S. (2013a). El día después: La sociología de las migraciones en tiempos de crisis [The day after: The sociology of migration in times of crisis]. Revista Española de Sociología, (19), 171-186. Retrieved from http://www. fes-sociologia.com/files/res/19/12.pdf

Rinken, S. (2013b). Enhancing representativeness in highly dynamic settings: Lessons from the NEPIA survey. In J. Font \& M. Méndez (Eds.), Surveying ethnic minorities and immigrant populations (pp. 85-108). Amsterdam, Netherlands: Amsterdam University Press.

Rinken, S. (2015). Actitudes hacia la emigración y los emigrantes: ¿En qué es España excepcional? [Attitudes towards emigration and emigrants: What about Spain's excepcionalism?] Migraciones: Revista del Instituto Universitario sobre Migraciones, (37), 53-74. doi:10.14422/mig.i37.y2015.003

Rinken, S., \& Escobar Villegas, M. (2012). Opiniones y actitudes ante la inmigración en un contexto de crisis económica: Datos y reflexiones [Opinions and attitudes towards immigration in an economic crisis context: Data and reflections]. Documentación Social, (162), 99-116.
Thalhammer, E., Zucha, V., Enzenhofer, E., Salfinger, B., \& Ogris, G. (2001). Actitudes hacia los grupos minoritários en la Unión Europea: Un análisis especial de la Encuesta Eurobarómetro 2000. Viena, Austria: Observatorio Europeo del Racismo y la Xenofobia.

Villén, D. J., Sola, T., \& Hinojo, F. J. (2013). El alumnado autóctono ante la inmigración: Influencia de las experiencias familiares como emigrantes en la relación con sus compañeros inmigración [Native Students and inmigration: Influence of family experiences as emigrants in the relationship with their inmigrant school partners]. Journal for Educators, Teachers and Trainers, 4(2), 106121. Retrieved from http://jett.labosfor.com/index.php/ jett/article/viewFile/67/67

Clemente Rodriguez-Sabiote is a Professor at the Universidad of Granada.

Jose Alvarez-Rodríguez is a Professor at the University of Granada.

Rosa Pilar Gámez-Durán is a Primary School Teacher of the Junta de Andalucía.

Received: Dec. 15, 2015

1st Revision: Aug. 01, 2016

Approved: Aug. 23, 2016

How to cite this article:

Rodríguez-Sabiote, C., Alvarez-Rodríguez, J., \& GámezDurán, R. P. (2017). Comparative-causal study of the term immigration in students of the University of Granada, Spain. Paidéia (Ribeirão Preto), 27(68), 324-330. doi: 10.1590/1982-43272768201710 